Pavlo A. Sodomora, Lyubov V. Guter

Ukraine

Valentyna A. Tryndiuk

Ukraine

Ukraine

\title{
Student Storytelling for Communication Skill Development Online (in the Time of Covid-19 Quarantine)
}

DOI: 10.15804/tner.2021.63.1.12

\begin{abstract}
Along with switching to on-line conversations on a global level due to quarantine restrictions, the importance of English language competency, becomes from day to day more and more evident. Since the initiation of quarantine it has become essential for higher education institutions to launch the search on new forms and methods capable of not only teaching foreign language, but of developing creative thinking and communication skills in future professionals. The paper describes the specifics of storytelling as a modern communication tool, suggests a new approach to the development and evaluation of communication skills in English by the technique of student storytelling online and proves the effectiveness of this technique. The research was conducted on the basis of Foreign (Professional) Language Curricula at three Ukrainian Universities, namely: Danylo Halytsky Lviv National Medical University, Lutsk Pedagogical College, and Lesya Ukrainka Volyn National University. The research included 78 participants (16-18 years old). The technique, based on the developmental and evaluation criteria related to the structure and style of the whole online student story, was tested in three stages - introductory, intermediate and final evaluation of online student storytelling skills. Each of the stages was followed by the training on the rules and strategies for effective storytelling and individual analysis of student's mistakes. By the results of the pilot study, all of the three experimental stages are characterized by the dynamic increase in general level of online student storytelling skills $(\mathrm{p}<0.01)$. Thus, a designed technique for communication skills development and evaluation by means of student storytelling online has been proved to be effective.
\end{abstract}

Key words: student storytelling, communication skills, online classes, Ukrainian higher education institutions 


\section{Introduction}

While learning any foreign language, the key role is assigned to the development of communication skills, i.e. abilities we use for exchanging different kinds of information, i.e. stories. Ideas, feelings and impressions play a significant role in the process of sentence formation; they are crucial for any person to present themselves or exchange personal experience, and closely connected with one of new marketing trends, namely, storytelling, which is being hailed as the most powerful business skill for the next decade (Neely, 2014; Sole \& Wilson, 2002).

Storytelling, known as the art of reproducing and perceiving stories (Reseki, 2017), has been in use since Antiquity. Various stories and myths (Sebeok, 2000) are proved to be the best forms of messages. In general, storytelling is in the process of its rebirth around the world (Simmons, 2006, p. 15). Recent research of an American literary scholar J. Gottschall (2013, p. 184) characterizes humans as "storytelling animals" who evolutionary possess an instinct of storytelling. The researcher describes the potential of stories to "change the world for the better", including the chances of improving the skills of speaking a foreign language (Gottschall, 2013, p. 184).

Storytelling as a tool of developing speaking skills has been researched by A. Akgun, H. Keskin, H. Ayar, and E. Erdogan (2015), and I. Rezeki (2017). Compared to other methods of teaching foreign languages the researched one is aimed at conversation skills development (Sutton, 2015; Chomsky, 2002; Stables, 2018). Use of student storytelling as a tool of English communication skills development has been already adopted in Ukrainian education system (Makovetska-Gudz, 2017). Teacher storytelling has been researched by Yu. Makovetska-Gudz (2017) nad I. Rezeki (2017) who prove the possibility of adapting this method to nearly all possible topics (Gottschall, 2013) and even to reporting medical cases (Sandars, Murray \& Pellow, 2008).

Since the initiation of quarantine it has become essential for many institutions to launch the search for new methods to be used not only in teaching foreign language, but in developing creative thinking of any given individual online. The newer approach to teaching a foreign language includes storytelling and its forms, e.g. natural monologue, facilitated discussion, debates, free dialogues, etc. However, there is a gap concerning the effectiveness of adequate techniques for evaluation of English storytelling skills. Thus, such technique has been designed and implemented in the academic process in the time of COVID-19 quarantine at three higher education institutions. 


\section{Methodology of Research}

The present study researches the effectiveness of a newly developed technique of storytelling as the potential tool for the development of professional English communication skills online. It was incorporated in the academic process of Danylo Halytsky Lviv National Medical University, Lutsk Pedagogical College, and Lesya Ukrainka Volyn National University. All stages of the research were conducted online. A total of 78 participants (16-18 years old) were randomly selected among the students of three mentioned above higher education institutions (10 per cent, 78 out of 780 students). In order to compare the differences by institutional affiliation the participants were divided into the three groups: first group - 36 medical students of Danylo Halytsky Lviv National Medical University, second group - 26 pre-school pedagogy students (with a focus in English) of Lutsk Pedagogical College, and the third group -16 Ukrainian philology students of Lesya Ukrainka Volyn national university respectively.

The pilot study consisted of the three main stages: introductory stage - primary evaluation of student storytelling skills online; intermediate stage - evaluation of student storytelling skills which was performed after providing of a 2-hour training on the rules and strategies for effective storytelling; and final stage - final evaluation of online student storytelling skills following the individual analysis of students' mistakes.

The approbation technique was based on the developmental and evaluation criteria categorized as two groups, namely (I) structure, and (II) style, thus resulting into the development of storytelling skills. Each of ten (eight structural and two stylistic components) were given minimum 0 points and maximum 10 points resulting in a maximum of 100 points, and they have been represented by the following items.

(I) According to the structure: 1) Setting - the story is supposed to be settled properly, which means specifying place, time, etc. 2) Characters are to be specified (name, age, gender, etc) in terms of their appropriateness to the story. 3) Theme or moral - it is important to demonstrate certain inferences in terms of morality. 4) Plot - it should be developed gradually and logically. 5) Conflict - the story benefits from conflict, challenge or problem properly settled.6) Climax - the most intense point of a story is to be composed properly. 7) Resolution - the story is supposed to have its appropriate resolution in accordance with the plot. 8) Tone - a story should impress, thus it should be clear whether the story is happy, funny, etc.

(II) In terms of its style that is primarily associated with a storytelling grammar, the story should exhibit 9) appropriate vocabulary, e.g. synonyms, or formal / 
informal vocabulary. 10) The grammar in the story provides a good possibility of assessing student's ability to use correctly different syntactic constructions.

The obtained data were statistically processed with the tools of Microsoft Excel, RStudio and R Commander. In case of normal distribution (by Shapiro-Wilk test) the data have been presented as a mean value $\pm S D$. In case of different from normal distribution the data were presented as median value (Percentile 25; Percentile 75). The significant differences have been found by the ANOVA method and further proved with the help of the post-hoc analysis by the paired comparison of first vs second, second vs third, and first vs third stages. The results were considered statistically significant when $\mathrm{p}$ value was $<0.05$.

\section{Results of the research}

It has been found that all of the three experimental stages are characterized by the dynamic increase in general level of student storytelling skills $(\mathrm{p}<0.01)$ (Figure 1).

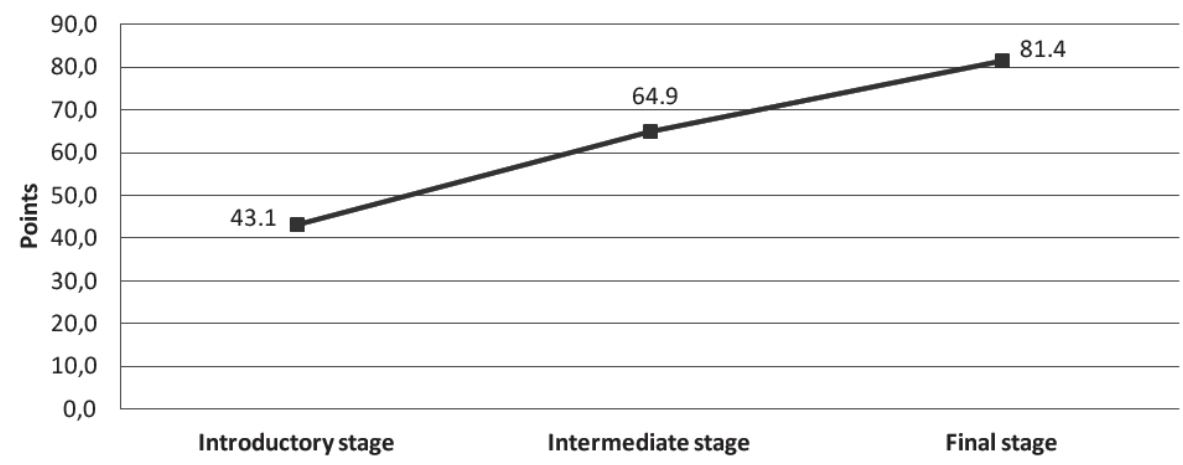

Figure 1. Dynamic progress in a general level of student online storytelling skills at three experimental stages

The analysis of both generalized and split student success rates by the stages indicated the developmental progress of online storytelling skills at all three stages $(p<0.01)$. The first - introductory level of overall student storytelling skills accounted for $43.1 \pm 13.7$ points out of a maximum number of 100 . The $2^{\text {nd }}-$ intermediate experimental stage, which was conducted after a specialized online classroom training of students on the effective strategy, recommendations and 
rules of storytelling, accounted for $64.9 \pm 16.5$ points out of 100 which was in 21.8 points higher than the former $(\mathrm{p}<0.01)$. The third, which was a final experimental stage indicated the increase of storytelling skills $(81.4 \pm 11.7$ points out of 100$)$ compared to both introductory $(\mathrm{p}<0.01)$ and intermediate stages $(\mathrm{p}<0.01)$.

Further detailed success rate analysis of storytelling skills in each of experimental groups indicated significant differences in the results by three research stages $(\mathrm{p}<0.01)$. The first group of students of Danylo Halytsky Lviv National Medical University showed better results at introductory and intermediate evaluation stages compared to the second and the third groups of students from Lutsk Pedagogical College and Lesya Ukrainka Volyn National University respectively $(\mathrm{p}<0.01)$ (Figure 2). Thus, the mean value of storytelling skills in the first group at the introductory level accounted for $47.2 \pm 15.8$ out of maximum 100 points, at intermediate level $-68.1 \pm 17.6$ out of maximum 100 points, and at a final stage $82.4 \pm 10.9$ out of maximum 100 points. The second group showed worse results at first two experimental stages, however at the final stage this group showed the best results compared to the first and the third groups. In addition, the significant difference has been found in the success rate of the third group compared to the first and the second ones at all the three experimental stages $(\mathrm{p}<0.01)$, which states the requirement for further analysis of the problem. Significant differences have not been found between the results of the first and the second experimental groups at all research stages $(\mathrm{p}>0.01)$.

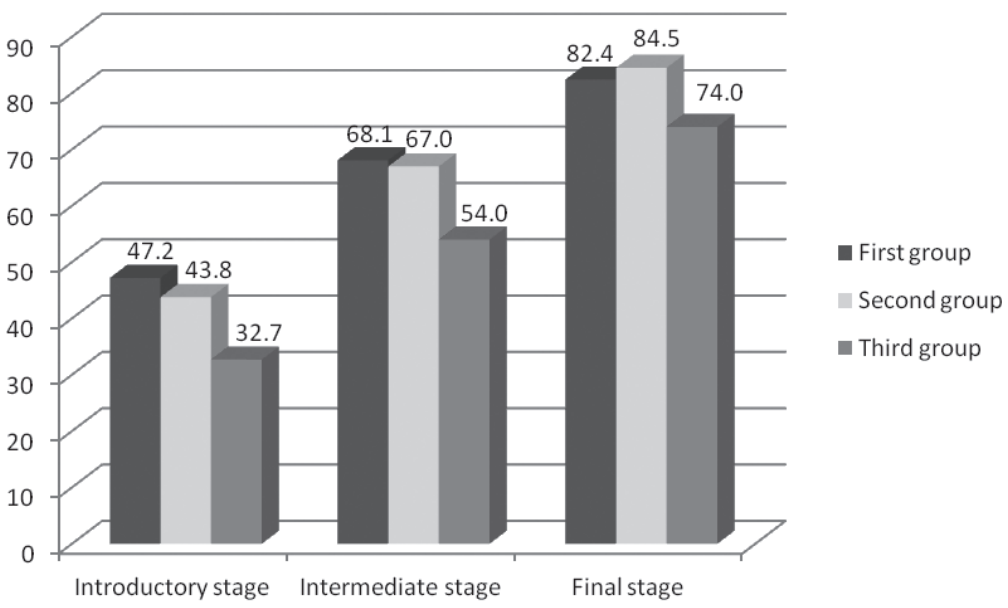

Figure 2. Comparison of success rates of online storytelling skills in three groups of students at the three research stages 
The analysis of all research results by evaluation criteria indicates the dynamic increase in storytelling skills in all participants of the research (Table 1). The most significant differences in the results concern the ability of students to describe characters $(p<0.01)$, while the comparative analysis by evaluation criteria indicates significant differences at all the three experimental stages $(\mathrm{p}<0.01)$.

Table 1. Dynamics of storytelling skills development by evaluation criteria in all participants of the pilot study

\begin{tabular}{lccc}
\hline $\begin{array}{c}\text { Evaluation } \\
\text { criteria }\end{array}$ & $\begin{array}{c}\text { Introductory stage } \\
\text { Mean } \pm \text { SD /median } \\
\text { value (Percentile 25; } \\
\text { Percentile 75) }\end{array}$ & $\begin{array}{c}\text { Intermediate stage } \\
\text { Mean } \pm \text { SD /median } \\
\text { value (Percentile 25; } \\
\text { Percentile 75) }\end{array}$ & $\begin{array}{c}\text { Final stage } \\
\text { (Mean } \pm \text { SD /median } \\
\text { value (Percentile 25; } \\
\text { Percentile 75) }\end{array}$ \\
\hline Setting & $40.0 \pm 15.5$ & Structure & $77.7 \pm 16.1$ \\
\hline Characters & $43.6 \pm 14.3$ & $59.2 \pm 17.8$ & $81.3 \pm 15.9$ \\
\hline Theme & $0.0(0.0 ; 0.0)$ & $62.6 \pm 18.1$ & $100.0(100.0 ; 100.0)$ \\
\hline Plot & $41.5 \pm 18.2$ & $65.6 \pm 20.1$ & $80.8 \pm 15.3$ \\
\hline Conflict & $0.0(0.0 ; 100.0)$ & $100.0(0.0 ; 100.0)$ & $100.0(100.0 ; 100.0)$ \\
\hline Climax & $35.9 \pm 17.7$ & $60.1 \pm 20.1$ & $74.7 \pm 20.6$ \\
\hline Resolution & $42.8 \pm 17.0$ & $67.9 \pm 20.0$ & $78.5 \pm 16.0$ \\
\hline Tone & $45.0 \pm 17.0$ & $67.6 \pm 17.5$ & $77.8 \pm 13.6$ \\
\hline \multicolumn{5}{c}{ Style } \\
\hline Vocabulary & $57.8 \pm 14.7$ & $70.1 \pm 13.6$ & $76.0 \pm 15.6$ \\
\hline Grammar & $57.6 \pm 16.6$ & $68.5 \pm 15.3$ & \\
\hline
\end{tabular}

The analysis of all research results by both evaluation criteria and research groups indicates the dynamic increase in storytelling skills in all participants of the research as well (Table 2). The signifficant differences have been found by comparison of data by all evaluation criteria at introductory vs final research stages $(\mathrm{p}<0.01)$. However, based on the results of a comparative data analysis of intermediate and final stages, signifficant differences have not been found in the development of storytelling skills concerning expressing tone of the story, as well as correct vocabulary and grammar use $(\mathrm{p}>0.05)$. Moreover, by the criterion of grammar, no signifficant difference has been found while comparing introductory and intermediate stages of online storytelling skills evaluation $(\mathrm{p}>0.05)$. 
Table 1. Storytelling skills dynamics by evaluation criteria and research groups

\begin{tabular}{|c|c|c|c|c|c|c|c|c|c|}
\hline \multirow[t]{2}{*}{$\begin{array}{l}\text { Evaluation } \\
\text { criteria }\end{array}$} & \multicolumn{3}{|c|}{$\begin{array}{c}\text { Introductory stage } \\
\text { (Mean } \pm \text { SD /median } \\
\text { value (Percentile } 25 ; \\
\text { Percentile } 75)\end{array}$} & \multicolumn{3}{|c|}{$\begin{array}{c}\text { Intermediate stage } \\
\text { (Mean } \pm \text { SD /median } \\
\text { value (Percentile } 25 ; \\
\text { Percentile } 75)\end{array}$} & \multicolumn{3}{|c|}{$\begin{array}{c}\text { Final stage } \\
\text { (Mean } \pm \text { SD /median } \\
\text { value (Percentile 25; } \\
\text { Percentile 75) }\end{array}$} \\
\hline & $\begin{array}{c}1^{\text {st }} \\
\text { group }\end{array}$ & $\begin{array}{c}2^{\text {nd }} \\
\text { group }\end{array}$ & $\begin{array}{c}3^{\text {rd }} \\
\text { group }\end{array}$ & $\begin{array}{c}1^{\text {st }} \\
\text { group }\end{array}$ & $\begin{array}{c}2^{\text {nd }} \\
\text { group }\end{array}$ & $\begin{array}{c}3^{\text {rd }} \\
\text { group }\end{array}$ & $\begin{array}{c}1^{\text {st }} \\
\text { group }\end{array}$ & $\begin{array}{c}2^{\text {nd }} \\
\text { group }\end{array}$ & $\begin{array}{c}3^{\text {rd }} \\
\text { group }\end{array}$ \\
\hline \multicolumn{10}{|c|}{ Structure } \\
\hline Setting & $\begin{array}{c}46.7 \\
\pm 16.6 \\
\end{array}$ & $\begin{array}{c}33.8 \\
\pm 11.0 \\
\end{array}$ & $\begin{array}{c}35.0 \\
\pm 13.7 \\
\end{array}$ & $\begin{array}{c}65.0 \\
\pm 18.1 \\
\end{array}$ & $\begin{array}{c}57.7 \\
\pm 15.3 \\
\end{array}$ & $\begin{array}{c}48.8 \\
\pm 16.3 \\
\end{array}$ & $\begin{array}{c}80.0 \\
\pm 15.1 \\
\end{array}$ & $\begin{array}{c}80.0 \\
\pm 16.0 \\
\end{array}$ & $\begin{array}{c}68.8 \\
\pm 16.3 \\
\end{array}$ \\
\hline Characters & $\begin{array}{c}50.6 \\
\pm 17.6\end{array}$ & $\begin{array}{l}38.5 \\
\pm 5.4\end{array}$ & $\begin{array}{c}35 \\
\pm 13.7\end{array}$ & $\begin{array}{c}71.7 \\
\pm 18.1\end{array}$ & $\begin{array}{c}58.5 \\
\pm 13.8\end{array}$ & $\begin{array}{l}48.75 \\
\pm 16.3\end{array}$ & $\begin{array}{c}82.2 \\
\pm 16.4\end{array}$ & $\begin{array}{c}83.8 \\
\pm 15.0\end{array}$ & $\begin{array}{r}68.75 \\
\pm 16.3 \\
\end{array}$ \\
\hline Theme & $\begin{array}{c}0.0 \\
(0.0 \\
100.0)\end{array}$ & $\begin{array}{l}0.0 \\
(0.0 \\
0.0)\end{array}$ & $\begin{array}{c}0.0 \\
(0.0 \\
0.0)\end{array}$ & $\begin{array}{c}100.0 \\
(0.0 \\
100.0)\end{array}$ & $\begin{array}{c}100.0 \\
(0.0 \\
100.0)\end{array}$ & $\begin{array}{c}0.0 \\
(0.0 \\
100.0)\end{array}$ & $\begin{array}{l}100.0 \\
(100.0 ; \\
100.0)\end{array}$ & $\begin{array}{l}100.0 \\
(100.0 ; \\
100.0)\end{array}$ & $\begin{array}{l}100.0 \\
(100.0 ; \\
100.0)\end{array}$ \\
\hline Plot & $\begin{array}{c}50.6 \\
\pm 18.2 \\
\end{array}$ & $\begin{array}{c}34.6 \\
\pm 15.6 \\
\end{array}$ & $\begin{array}{c}32.5 \\
\pm 12.4 \\
\end{array}$ & $\begin{array}{c}73.9 \\
\pm 19.0 \\
\end{array}$ & $\begin{array}{c}61.5 \\
\pm 18.7 \\
\end{array}$ & $\begin{array}{r}53.75 \\
\pm 17.5 \\
\end{array}$ & $\begin{array}{c}85.0 \\
\pm 15.4 \\
\end{array}$ & $\begin{array}{c}81.5 \\
\pm 12.6 \\
\end{array}$ & $\begin{array}{c}70 \\
\pm 14.6 \\
\end{array}$ \\
\hline Conflict & $\begin{array}{c}0.0 \\
(0.0 \\
100.0)\end{array}$ & $\begin{array}{c}100.0 \\
(0.0 \\
100.0)\end{array}$ & $\begin{array}{c}0.0 \\
(0.0 \\
0.0)\end{array}$ & $\begin{array}{l}100.0 \\
(100.0 ; \\
100.0)\end{array}$ & $\begin{array}{l}100.0 \\
(100.0 ; \\
100.0)\end{array}$ & $\begin{array}{c}0.0 \\
(0.0 \\
0.0)\end{array}$ & $\begin{array}{l}100.0 \\
(100.0 ; \\
100.0)\end{array}$ & $\begin{array}{l}100.0 \\
(100.0 ; \\
100.0)\end{array}$ & $\begin{array}{c}100.0 \\
(0.0 \\
100.0)\end{array}$ \\
\hline Climax & $\begin{array}{c}39.2 \\
\pm 23.7 \\
\end{array}$ & $\begin{array}{c}34.1 \\
\pm 10.3 \\
\end{array}$ & $\begin{array}{c}31.25 \\
\pm 7.9 \\
\end{array}$ & $\begin{array}{c}63.2 \\
\pm 24.3 \\
\end{array}$ & $\begin{array}{c}62.0 \\
\pm 13.0 \\
\end{array}$ & $\begin{array}{c}50 \\
\pm 16.5 \\
\end{array}$ & $\begin{array}{c}78.1 \\
\pm 22.6 \\
\end{array}$ & $\begin{array}{c}75.5 \\
\pm 17.1 \\
\end{array}$ & $\begin{array}{l}65.63 \\
\pm 19.6 \\
\end{array}$ \\
\hline Resolution & $\begin{array}{c}51.7 \\
\pm 16.8 \\
\end{array}$ & $\begin{array}{l}34.62 \\
\pm 13.3 \\
\end{array}$ & $\begin{array}{l}36.25 \\
\pm 13.1 \\
\end{array}$ & $\begin{array}{c}73.9 \\
\pm 20.2 \\
\end{array}$ & $\begin{array}{r}65.38 \\
\pm 18.4 \\
\end{array}$ & $\begin{array}{c}58.75 \\
\pm 18.57 \\
\end{array}$ & $\begin{array}{c}85.0 \\
\pm 13.8 \\
\end{array}$ & $\begin{array}{l}80.77 \\
\pm 16.5 \\
\end{array}$ & $\begin{array}{c}75 \\
\pm 18.62 \\
\end{array}$ \\
\hline Tone & $\begin{array}{c}51.0 \\
\pm 21.6 \\
\end{array}$ & $\begin{array}{l}40.87 \\
\pm 10.3 \\
\end{array}$ & $\begin{array}{c}38.28 \\
\pm 7.2 \\
\end{array}$ & $\begin{array}{c}68.8 \\
\pm 19.7 \\
\end{array}$ & $\begin{array}{r}68.75 \\
\pm 14.7 \\
\end{array}$ & $\begin{array}{r}63.28 \\
\pm 16.8 \\
\end{array}$ & $\begin{array}{c}77.1 \\
\pm 18.8 \\
\end{array}$ & $\begin{array}{l}82.21 \\
\pm 15.1 \\
\end{array}$ & $\begin{array}{r}74.22 \\
\pm 18.5 \\
\end{array}$ \\
\hline \multicolumn{10}{|c|}{ Style } \\
\hline $\begin{array}{l}\text { Vocabu- } \\
\text { lary }\end{array}$ & $\begin{array}{c}58.6 \\
\pm 16.8 \\
\end{array}$ & $\begin{array}{l}56.15 \\
\pm 13.9 \\
\end{array}$ & $\begin{array}{l}58.44 \\
\pm 11.5 \\
\end{array}$ & $\begin{array}{c}69.7 \\
\pm 15.6 \\
\end{array}$ & $\begin{array}{l}70.77 \\
\pm 12.6 \\
\end{array}$ & $\begin{array}{c}70 \\
\pm 11.0 \\
\end{array}$ & $\begin{array}{c}73.9 \\
\pm 15.5 \\
\end{array}$ & $\begin{array}{l}81.54 \\
\pm 11.9 \\
\end{array}$ & $\begin{array}{c}80.63 \\
\pm 9.3 \\
\end{array}$ \\
\hline Grammar & $\begin{array}{c}62.5 \\
\pm 17.1\end{array}$ & $\begin{array}{l}53.85 \\
\pm 16.5\end{array}$ & $\begin{array}{c}52.5 \\
\pm 12.9\end{array}$ & $\begin{array}{c}70.0 \\
\pm 17.9\end{array}$ & $\begin{array}{r}68.08 \\
\pm 13.3 \\
\end{array}$ & $\begin{array}{l}65.63 \\
\pm 12.1\end{array}$ & $\begin{array}{c}73.9 \\
\pm 18.4\end{array}$ & $\begin{array}{l}79.23 \\
\pm 13.5\end{array}$ & $\begin{array}{r}75.63 \\
\pm 10.9\end{array}$ \\
\hline
\end{tabular}

The comparative analysis by storytelling evaluation criteria of (I) structure and the (II) style indicates significant differences in the development of storytelling skills at introductory vs final stages $(\mathrm{p}<0.01)$ (Figure 3 ).

The storytelling skills concerning structure of the story improved significantly at intermediate vs final research stages $(\mathrm{p}<0.01)$ (Figure 4). However, the stylistic storytelling skills concerning the correct vocabulary and grammar use have not improved and no significant differences have been found in result of their comparison $(\mathrm{p}>0.05)$. 


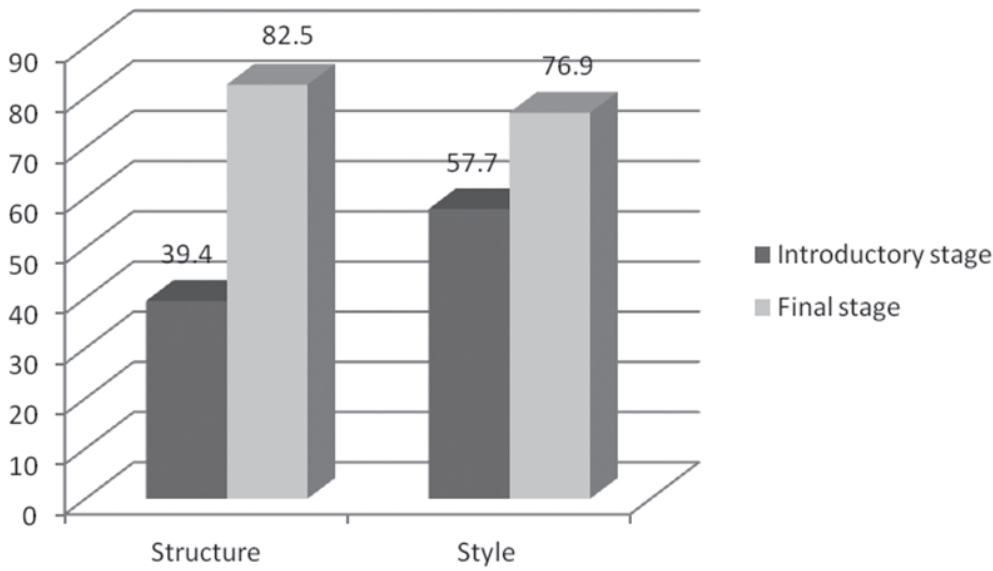

Figure 3. Development of storytelling skills categorized by structure and the style at introductory vs final research stages

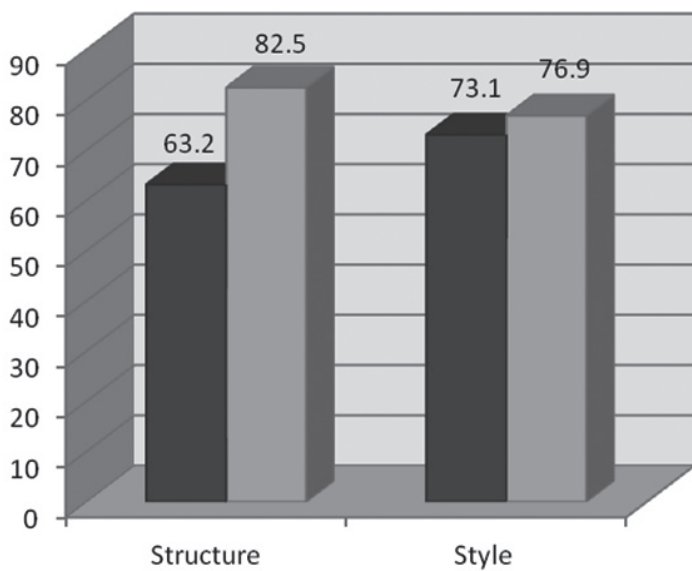

- Intermediate stage $\square$ Final stage

Figure 4. Development of storytelling skills categorized by structure and the style at intermediate vs final research stages 


\section{Discussion}

The conducted pilot research proves insufficient student's literacy (43.1 points out of a maximum of 100 points at the introductory stage): their ineptness to speak fluently and correctly, to provide logical assumptions, etc. Factors influencing poor introductory evaluation results include: 1) insufficient level of general English;2) the lack of a reading activity in English or even in their native language; 3 ) adhering to the style of mobile device communication and being deprived of deep linguistic thinking; 4) the lack of motivation to study online (Lukianova, 2016) and primary inconvenience to communicate and interact at online classes (Maniuk, 2016). However, insufficient level of storytelling skills online in all participants is primarily associated with the lack of knowledge on storytelling techniques.

In addition, the results of the conducted experiment prove the research hypothesis of the possibility of storytelling skills development by the designed methodology directed at acknowledging on structural and stylistic story features (Figure 1). Profound statistical analysis discovered significant differences between all experimental stages $(\mathrm{p}<0.01)$. The dynamic increase in general level of online student storytelling skills at all of the three experimental stages indicates the validity and effectiveness of a developed methodology of storytelling skills development and evaluation.

The fact that the results improved from stage to stage proves the efficacy of a storytelling skills development technique as an effective method of delivering information to the audience (Armstrong, 1992) and making the audience compile their own story, using their active vocabulary. The method of online student storytelling helps evoke passive vocabulary, i.e. vocabulary which is remembered but not used for speaking. Besides, it is effective for initialization of conversations between students and professors, which can be performed by suggesting students to tell their own real or unreal stories. This helps students fight their unnecessary fears and complexes, which prevent them from speaking. It was believed initially that only in-class courses can provide active, cooperative, and alert learning during actual class time. But, the research results prove that online classes offer the same efficient learning and have the potential for the development of professional and communication skills. Thus, there is the requirement for the implementation of our experimental technique into the curricula of higher education institutions by different specialties.

Obtained positive results do not depend on the institutional affiliation and specialty, as the analysis of dynamics in storytelling skills formation in each of the 
experimental groups indicates significant differences $(p<0.01)$ between all research stages. However, the analysis of general dynamics in all experimental groups by the ten evaluation criteria indicated significant differences between individual group results $(\mathrm{p}<0.01)$. The following results can be explained by specialization of students in these groups, as the students of Lesya Ukrainka Volyn National University had more intensive English curriculum compared to other experimental groups. The students of the institution mentioned above received the highest final evaluation grade by the criterion of (II) style aimed at evaluating vocabulary and grammar skills that can also be explained by the influence of abovementioned factor.

It has been expected that vocabulary and grammar skills would not improve drastically in this experimental study as it is well known that the development of these skills requires much time and effort (Maniuk, 2016). All participants were instructed on specific storytelling grammar and vocabulary use before the intermediate evaluation stage which was followed by the analysis of their mistakes, however the results prove insufficiency of such instruction for the statistically significant difference between the intermediate and final evaluation stages. Thus, the effectiveness of our storytelling skills development technique depends directly on the level of English.

Well-established goal defines and significantly influences the result. This partially explains why a group of medical students (Danylo Halytsky Lviv National Medical University), knowing that they are obliged to take their English Language qualification exam, appeared to be more persistent in learning English and showed better results at first two experimental stages (Figure 2). Comparatively better introductory level of English thus resulting in better storytelling skills of medical students could be explained by the entrance requirement of a high competition grade of State Independent Evaluation ( $>150$ points) for medical students. The third reliable key driver of medical students getting better scores can be referred to relatively narrow specifics of the subject, i.e medicine. Having the genre of a story fixed, and being conversant with the professional vocabulary, it is comparatively straightforward task to compile a story using more or less simple sentences.

The method of online student storytelling poses certain requirements to both teachers and students (Sodomora, 2009), however it results in student's better understanding of grammatical structures, proper application of composition of sentences, and clear use of vocabulary. Those are the results which can be achieved by storytelling method during online classes. 


\section{Conclusions}

The research has proved the effectiveness of a new technique for communication skills development and evaluation online by means of student storytelling that was implemented in the academic process of three Ukrainian higher education institutions. Storytelling online was motivating for students, enabled fluent speaking and active discussion which was rather challenging in conditions of urgent worldwide transfer to distance learning due to COVID -19 pandemic.

In addition, a technique of student storytelling provides precise, consistent and efficient structural and stylistic criteria for evaluation. It can be administered in order to involve students into linguistic thinking, and to develop their language skills as a consequence. This approach can vitalize the academic process, improve scoring, and involve students into the action during online classes.

Thus, the research results support introducing student storytelling as new approach to teaching a foreign language online. One of further directions of the research is a comparative effectiveness of the technique for the online and in-class learning.

\section{References}

Akgun, A., Keskin H., Ayar H., \& Erdogan E. (2015) The Influence of Storytelling Approach. Procedia - Social and Behavioral Sciences, 207, 577-586. Retrieved 25/09/2020, from https://www.sciencedirect.com/science/article/pii/S1877042815052623

Armstrong, D.M. (1992). Managing by Storying Around: A New Method of Leadership. New York: Doubleday Currency.

Chomsky, N. (2002). On Nature and Language. Cambridge: Cambridge University Press. Gottschall, J. (2013). The Storytelling Animal: How Stories Make Us Human. New York.

Lukianova, L. (2016). Motivation Factors of Adult Learning. The New Educational Review, 44, 223-229. Retrieved 30/09/2020, from https://tner.polsl.pl/e44/a18.pdf

Makovetska-Gudz, Yu. (2017) (Storytelling in teaching practice). Zbiór artykułów naukowych Konferencji Miedzynarodowej NaukowoPraktycznej "Pedagogika. Teoretyczne i praktyczne aspekty rozwoju współczesnej nauki” (30.03.2017 - 31.03.2017). Warszawa: "Diamond trading tour", 9-13. (in Ukrainian). Retrieved 10/09/2020, from http:// xn--elaajfpcds8ay4h.com.ua/files/scientific_conference_63/63-32.pdf

Maniuk, L.V. (2016). Social media in the process of professional and communicative skills training of future physicians. Information Technologies and Learning Tools, 53 (3), 88-97.

Neely, P. (2014). Storytelling Techniques and How to Apply Them. Practical Ecommerce. Retrieved 10/09/2020, from https://www.practicalecommerce.com/7-storytelling-techniques-and-how-to-apply-them 
Rezeki, I. (2017). Using Storytelling Technique to Improve Speaking Ability at Insan Qur'ani Boarding School Aceh Besar. Thesis for the Degree on Teacher Education, Fakultas Tarbiyah dan Keguruan, Pendidikan Bahasa Inggris. Retrieved 10/11/2020, from https://core.ac.uk/download/pdf/293467043.pdf

Sandars, J. Murray, C. \& Pellow, A. (2008). Twelve tips for using digital storytelling to promote reflective learning by medical students. Medical Teacher, 30 (8), 774-777. Retrieved 29/10/2020, from https://www.tandfonline.com/doi/full/10.1080/01421590801987370

Sebeok, Th. \& A.; Danesi, M. (2000). The Forms of Meaning: Modeling Systems Theory and Semiotic Analysis. Berlin: Mouton de Gruyter.

Simmons, A. (2006). The Story Factor: Inspiration, Influence, and Persuasion through the Art of Storytelling. Perseus, N.Y.

Sodomora, P. (2009). Synonyms and Identity of Denotation: a Problem in the Semiotics of Translation. Semiotics Society proceedings: Legas, New York, 745-750.

Sole D. \& Wilson D. (2002). Storytelling in organizations: The power and traps of using stories to share knowledge in organizations. LILA, Harvard. Retrieved 20/09/2020, from https://www.researchgate.net/publication/242189756_Storytelling_in_Organizations_The_power_and_traps_of_using_stories_to_share_knowledge_in_organizations

Stables, A. (2018). Semiotic Theory of Learning: New Perspective in the Philosophy of Education. Routledge.

Sutton, J. (2015). Remembering as Public Practice: Wittgenstein, Memory, and Distributed Cognitive Ecologies. Moyal-Sharrock, Munz, \& Coliva, 409-443. 